\title{
Tat-ATOX1 inhibits streptozotocin-induced cell death in pancreatic RINm5F cells and attenuates diabetes in a mouse model
}

\author{
EUN HEE AHN ${ }^{1 *}$, DAE WON KIM ${ }^{2 *}$, MIN JEA SHIN ${ }^{1}$, EUN JI RYU ${ }^{1}$, JI IN YONG ${ }^{1}$, SEOK YOUNG CHUNG ${ }^{1,6}$, \\ HYUN JU CHA ${ }^{1}$, SANG JIN KIM ${ }^{1}$, YEON JOO CHOI ${ }^{1}$, DUK-SOO KIM ${ }^{3}$, SUNG-WOO CHO ${ }^{4}$, KEUNWOOK LEE ${ }^{1}$, \\ YOON SHIN CHO ${ }^{1}$, HYEOK YIL KWON ${ }^{5}$, JINSEU PARK ${ }^{1}$, WON SIK EUM ${ }^{1}$ and SOO YOUNG CHOI ${ }^{1}$ \\ ${ }^{1}$ Department of Biomedical Science and Research Institute of Bioscience and Biotechnology, Hallym University, \\ Chuncheon, Gangwon-do 24252; ${ }^{2}$ Department of Biochemistry and Molecular Biology, Research Institute of Oral Sciences, \\ College of Dentistry, Gangneung-Wonju National University, Gangneung, Gangwon-do 25457; ${ }^{3}$ Department of Anatomy, \\ College of Medicine, Soonchunhyang University, Cheonan-Si, Chungnam 31538; ${ }^{4}$ Department of Biochemistry \\ and Molecular Biology, University of Ulsan College of Medicine, Seoul 05505; ${ }^{5}$ Department of Physiology, \\ College of Medicine, Hallym University, Chuncheon, Gangwon-do 24252, Republic of Korea
}

Received May 6, 2015; Accepted April 27, 2016

DOI: $10.3892 / \mathrm{ijmm} .2016 .2599$

\begin{abstract}
Antioxidant 1 (ATOX1) functions as an antioxidant against hydrogen peroxide and superoxide, and therefore may play a significant role in many human diseases, including diabetes mellitus (DM). In the present study, we examined the protective effects of Tat-ATOX1 protein on streptozotocin (STZ)-exposed pancreatic insulinoma cells (RINm5F) and in a mouse model of STZ-induced diabetes using western blot analysis, immunofluorescence staining and MTT assay, as well as histological and biochemical analysis. Purified Tat-ATOX1 protein was efficiently transduced into RINm5F cells in a dose- and time-dependent manner. Additionally, Tat-ATOX1 protein markedly inhibited reactive oxygen species (ROS) production, DNA damage and the activation of Akt and mitogen activated protein kinases (MAPKs) in STZ-exposed RINm5F cells. In addition, Tat-ATOX1 protein transduced into mice pancreatic tissues and significantly decreased blood glucose and hemoglobin A1c (HbA1c) levels as well as the body weight changes in a model of STZ-induced diabetes. These results indicate that
\end{abstract}

Correspondence to: Dr Won Sik Eum or Dr Soo Young Choi, Department of Biomedical Science and Research Institute of Bioscience and Biotechnology, Hallym University, 1 Hallymdaehak-gil, Chuncheon, Gangwon-do 24252, Republic of Korea

E-mail:wseum@hallym.ac.kr

E-mail: sychoi@hallym.ac.kr

Present address: ${ }^{6}$ Shaker High School, Latham, NY 12110, USA

*Contributed equally

Key words: Tat-antioxidant 1, diabetes mellitus, blood glucose, hemoglobin A1c, oxidative stress, protein therapy transduced Tat-ATOX1 protein protects pancreatic $\beta$-cells by inhibiting STZ-induced cellular toxicity in vitro and in vivo. Based on these findings, we suggest that Tat-ATOX1 protein has potential applications as a therapeutic agent for oxidative stress-induced diseases including DM.

\section{Introduction}

Diabetes mellitus (DM) is characterized by hyperglycemia caused by a lack of or resistance to insulin, and it affects approximately 422 million individuals worldwide (1). In addition, it is well known that DM is an important metabolic disease which causes a variety of complications, including certain types of cancer and hepatic glucose production (2-4). Although the precise mechanisms involved remain poorly understood, oxidative stress is believed to be one of the major factors contributing to DM. Several previous studies have demonstrated that excessive oxidative stress is generated in response to pancreatic $\beta$-cell death in animal models of streptozotocin (STZ)-induced diabetes (5-7).

Antioxidant 1 (ATOX1) is abundantly expressed in various areas of the brain, including the cerebral cortex and hippocampus, where it plays important roles in copper homeostasis and acts as a copper chaperone. Additionally, ATOX1 is known to function as an antioxidant which protects against oxidative stress and as a copper-dependent transcription regulator, which also involves the regulation of cell proliferation, the cell cycle and superoxide dismutase 3, extracellular (SOD3) (8-10). Copper is a co-factor required in various biological processes; however, excess copper causes toxicity in cells (11-13). Previous studies have demonstrated that ATOX1 plays an important role in cell survival in various diseases, including cancer, hypertension, cardiovascular disease and neuronal diseases, suggesting that ATOX1 is a potential therapeutic target molecule for the use in the management of patients suffering from disorders of copper metabolism and oxidative stress-induced diseases (14-19). 
Despite ATOX1 having the potential to be used as a therapeutic target molecule in the fight against a variety of diseases, the applications of ATOX1 are limited by an inability to deliver it into cells or tissues. Protein transduction domains (PTDs) or cell-penetrating peptides (CPPs) have helped to overcome this limitation by allowing target molecules to be transduced into cells and tissue. Tat peptide is comprised of 9 amino acids (RKKRRQRRR), and it delivers proteins into cells and tissues such as brain cells (20-22). Several studies, including those undertaken by our group, have demonstrated that various Tat-fused proteins transduce into cells and protect against cell death in various diseases (23-29).

In the present study, we examined the protective effects of Tat-ATOX1 protein in STZ-exposed RINm5F cells and in a mouse model of STZ-induced diabetes. We found that Tat-ATOX1 protein transduced into the RINm5F cells and pancreatic tissues. Transduced Tat-ATOX1 protein markedly protected against STZ-induced cell death in vitro and in vivo. Therefore, we suggest that Tat-ATOX1 protein has potential applications as a therapeutic agent for oxidative stress-related diseases including DM.

\section{Materials and methods}

Materials. Tat peptide was chemically synthesized by Peptron (Daejeon, Korea). The rat pancreatic insulinoma cell line RINm5F was purchased from the American Type Culture Collection (ATCC; Manassas, VA, USA). STZ was purchased from Sigma-Aldrich (St. Louis, MO, USA). An $\mathrm{Ni}^{2+}$-nitrilotriacetic acid Sepharose superflow was purchased from Qiagen (Valencia, CA, USA). RPMI-1640 medium and antibiotics were obtained from Invitrogen (Carlsbad, CA, USA). Fetal bovine serum (FBS) was purchased from Lonza (Basel, Switzerland). Primary antibodies [histidine (sc-804), insulin (sc-8033), Akt (9273), p-Akt (4058), JNK (9258), p-JNK (9251), p38 (9212), p-p38 (4631), beta-actin (4967) and HRP-conjugated antibodies (7074)] were obtained from Santa Cruz Biotechnology, Inc. (Santa Cruz, CA, USA) and Cell Signaling Technology (Beverly, MA, USA). Human ATOX1 cDNA was isolated using the PCR technique. All other chemicals and reagents were of the highest quality grade available.

Purification of Tat-ATOX1 protein. The Tat expression vector was prepared in our laboratory as described previously (24). Briefly, the cDNA sequence for human ATOX1 was PCR amplified using the sense and antisense primers: ATOX1 sense, 5'-CTCGAGATGCCGAAGCACG-3' and antisense, 5'-GGATCCCTACTCAAGGCCAAGG-3'. The PCR products were then sub-cloned into a TA vector (Promega, Madison, WI, USA) and ligated into the Tat expression vector to generate the Tat-ATOX1 expression vector. We generated ATOX1 protein without the Tat peptide as a control. The recombinant Tat-ATOX1 plasmid was transformed into Escherichia coli BL21 (DE3; Novagen, Madison, WI, USA) and cultured in $0.5 \mathrm{mM}$ isopropyl- $\beta$-D-thiogalactoside (IPTG; Duchefa, Haarlem, The Netherlands) at $18^{\circ} \mathrm{C}$ overnight. The harvested cells were purified using an $\mathrm{Ni}^{2+}$-nitrilotriacetic acid Sepharose affinity column and PD-10 column chromatography (Amersham, Piscataway, NY, USA) $(29,30)$. The concentration of purified protein was measured using the Bradford assay (Bio-Rad Laboratories, Hercules, CA, USA), as previously described (31).

Cell culture and transduction of Tat-ATOX1 protein. The RINm5F cells were cultured in RPMI-1640 medium containing $2 \mathrm{mM}$ glutamine, $10 \% \mathrm{FBS}$ and antibiotics $(100 \mu \mathrm{g} / \mathrm{ml}$ streptomycin, $100 \mathrm{U} / \mathrm{ml}$ penicillin) at $37^{\circ} \mathrm{C}$ in a humidified incubator containing $5 \% \mathrm{CO}_{2}$ and $95 \%$ air.

To examine the transduction ability of Tat-ATOX1 and control ATOX1 protein, the cells were treated with various doses of Tat-ATOX1 protein $(0.5-3 \mu \mathrm{M})$ for $30 \mathrm{~min}$ and over various periods of time (5-30 min) with $3 \mu \mathrm{M}$ of Tat-ATOX1 protein. Following treatment with Tat-ATOX1 protein, the cells were washed three times with phosphate-buffered saline (PBS) and trypsin-EDTA. The cells were then harvested and western blot analysis was performed.

Western blot analysis. Equal amounts of proteins were resolved by $15 \%$ sodium dodecyl sulfate-polyacrylamide gel electrophoresis (SDS-PAGE). Following electrophoresis, the proteins were transferred from the gel to a nitrocellulose membrane. The membrane was blocked with TBS-T buffer $(25 \mathrm{mM}$ Tris-HCl, $140 \mathrm{mM} \mathrm{NaCl}, 0.1 \%$ Tween-20, pH 7.5) containing $5 \%$ non-fat dry milk or bovine serum albumin (BSA). The membrane was incubated with primary and HRP-conjugated antibodies $(26,27,32)$. The bands were identified using chemiluminescent reagents according to the manufacturer's instructions (Amersham, Franklin Lakes, NJ, USA).

Confocal fluorescence microscopy. Confocal fluorescence microscopy was performed, as described previously $(27,33)$. Briefly, the RINm5F cells were grown on coverslips treated with Tat-ATOX1 protein $(3 \mu \mathrm{M})$ for $30 \mathrm{~min}$, and the cells were washed with PBS twice and fixed with $4 \%$ paraformaldehyde for $3 \mathrm{~min}$. The cells were then treated with the primary antibody (anti-histidine; 1:2,000) and Alexa Fluor 488-conjugated secondary antibody (1:15,000; Invitrogen). After the nuclei were stained with DAPI $(1 \mu \mathrm{g} / \mathrm{ml}$; Roche Applied Science, Mannheim, Germany) for $3 \mathrm{~min}$, the cells were observed under a confocal fluorescence microscope (FV-300; Olympus, Tokyo, Japan).

Cell viability assay. The RINm5F cells were plated at a confluence of $80 \%$ on a 96 -well plate and treated with various amounts of Tat-ATOX1 proteins $(1-3 \mu \mathrm{M})$ for $30 \mathrm{~min}$. The cells were incubated with $3 \mathrm{mM} \mathrm{STZ}$ for $12 \mathrm{~h}$. Subsequently, cell viability was determined by 3-(4,5-dimethylthiazol-2-yl)2,5-diphenyltetrazolium bromide (MTT) assay (Duchefa, Haarlem, The Netherlands). The absorbance was measured at $570 \mathrm{~nm}$ using an ELISA microplate reader (Labsystems Multiskan MCC/340; Labsystem Oy, Helsinki, Finland), and cell viability is presented as a percentage of the control cells, as previously described $(30,34)$.

Measurement of DNA damage. 8-Hydroxy-2'-deoxyguanosine (8-OHdG; Santa Cruz Biotechnology, Inc.) and terminal deoxynucleotidyl transferase (TdT)-mediated biotinylated dUTP nick end labeling (TUNEL; Roche Applied Science) staining was performed as described previously (27). The RINm5F cells were pre-treated with Tat-ATOX1 protein 
(3 $\mu \mathrm{M}$ ) for $30 \mathrm{~min}$, and then the cells were incubated with $3 \mathrm{mM} \mathrm{STZ}$ for $24 \mathrm{~h}$. Images were analyzed using a fluorescence microscope (Nikon Eclipse 80i; Nikon, Tokyo, Japan). The fluorescence intensity was measured using a Fluoroskan ELISA plate reader (Labsystems Oy).

Animals and experimental protocol. Male 5-week-old ICR mice were housed at $23^{\circ} \mathrm{C}$ and $60 \%$ humidity under a fixed 12-h light/dark cycle with free access to food and water. All experimental procedures involving the animals and their care conformed to the Guide for the Care and Use of Laboratory Animals of the National Veterinary Research and Quarantine Service of Korea and were approved by the Hallym Medical Center Institutional Animal Care and Use Committee.

The ICR mice were divided into the following six groups ( $n=10 /$ group): i) untreated normal control group, ii) STZ-injected group, iii) STZ + Tat-ATOX1 protein (2 $\mathrm{mg} / \mathrm{kg})$ injected group, iv) STZ + ATOX1 protein $(2 \mathrm{mg} / \mathrm{kg})$ injected group, v) STZ + Tat peptide ( $2 \mathrm{mg} / \mathrm{kg})$ injected group, and vi) STZ + insulin (0.02 IU; Sigma-Aldrich) injected group. To induce diabetes, the mice were injected intraperitoneally with STZ (Sigma-Aldrich) dissolved in $50 \mathrm{mM}$ sodium citrate buffer solution ( $\mathrm{pH} 4.5$; Sigma-Aldrich) at a dose of $70 \mathrm{mg} /$ $\mathrm{kg}$ body weight. The untreated normal control mice were injected with the same volume of sodium citrate buffer. The mice received 6 injections of Tat-ATOX1 protein, control ATOX1 protein, Tat peptide, and insulin at weekly intervals. The mice were sacrificed by cervical dislocation 8 weeks after inducing diabetes with STZ. Mice were perfused transcardially with phosphate-buffered saline (PBS) followed by $4 \%$ paraformaldehyde in $0.1 \mathrm{M}$ phosphate buffer ( $\mathrm{PB}, \mathrm{pH}$ 7.4) under urethane anesthesia $(1.5 \mathrm{~g} / \mathrm{kg}$, i.p.). The pancreatic tissues were removed for histological examinations. In order to analyze the pancreatic $\beta$-cells in the present study, tissue sections were incubated with either an anti-mouse insulin IgG (dilution 1:300; InnoGenex, San Ramon, CA, USA) or anti-His (dilution 1:200). The pancreatic tissue sections were stained with a peroxidas e/3,3'-diaminobenzidine (DAB) system kit (Dako EnVision kit; Dako, Glostrup, Denmark) or hematoxylin and eosin (H\&E; Sigma-Aldrich), as previously described (6).

Biochemical analysis. Changes in body weight and blood glucose levels were monitored weekly over the 8-week study period. Blood glucose levels were analyzed using an Accu-Chek glucose strip machine (Roche Applied Science) (35). To examine changes to blood glycated hemoglobin A1c (HbA1c) levels, blood samples were collected from the tail vein after 8 weeks. HbA1c levels were then measured using a glycohemoglobin analyzer (HLCr-723GHb; Tosoh Corp., Kyoto, Japan).

Statistical analysis. All experiments were performed three times. Data were analyzed using analysis of variance (ANOVA) and the Student's t-test. A P-value $<0.05$ was considered to indicate a statistically significant difference.

\section{Results}

Construction and purification of Tat-ATOX1 protein. The human ATOX1 gene was inserted into a pET-15b plasmid containing a Tat peptide PTD in order to generate a recom-
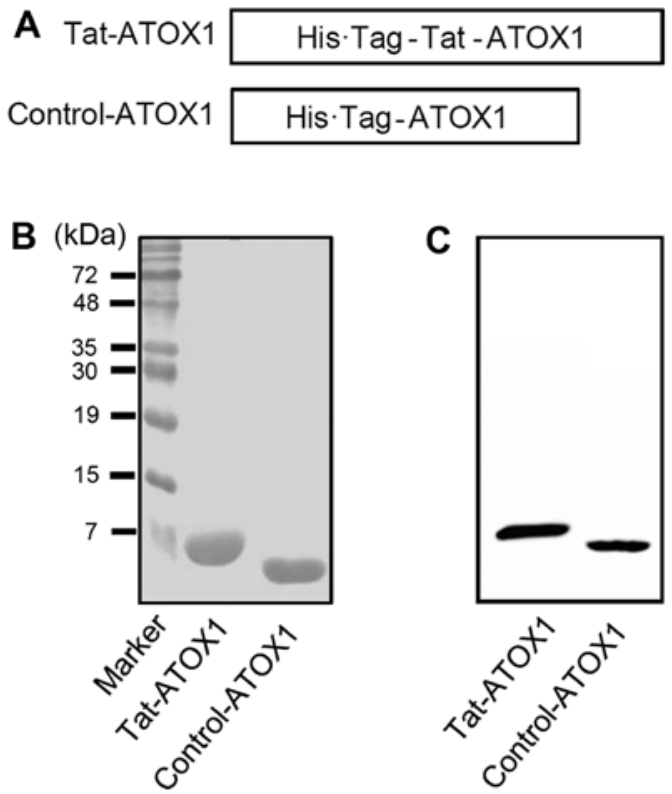

Figure 1. Purification of Tat-antioxidant 1 (ATOX1) protein. (A) Diagram of the expressed control ATOX1 and Tat-ATOX1 proteins. Each consists of a His tag with six histidine residues. Purified control ATOX1 and Tat-ATOX1 proteins were analyzed by (B) $15 \%$ SDS-PAGE and (C) western blot analysis with an anti-rabbit histidine antibody.

binant Tat-ATOX1 protein expression plasmid. The resulting recombinant Tat-ATOX1 plasmid was confirmed by automated sequencing analysis. The Tat-ATOX1 protein expression plasmid consisted of human ATOX1 cDNA, a Tat peptide, and a His tag with 6-histidine residues (Fig. 1A). The control ATOX1 protein expression plasmid containing no Tat peptide was also generated.

Following the culture of the Tat-ATOX1 and control protein in $0.5 \mathrm{mM}$ IPTG overnight at $18^{\circ} \mathrm{C}$, the proteins were purified using an $\mathrm{Ni}^{2+}$-nitrilotriacetic acid Sepharose affinity column and PD-10 column chromatography. The purified proteins were confirmed by SDS-PAGE (Fig. 1B). We also identified the proteins by performing western blot analysis with an antihistidine antibody (Fig. 1C). These results indicate that we successfully expressed and purified Tat-ATOX1 and control ATOX1 proteins.

Transduction of Tat-ATOX1 protein into RINm5F cells. The transduction ability of Tat-ATOX1 protein into the RINm5F cells was determined by western blot analysis and confocal microscopy. The RINm5F cells were treated with different concentrations of Tat-ATOX1 protein $(0.5-3 \mu \mathrm{M})$ for $30 \mathrm{~min}$ and over different periods of time (5-30 min) with $3 \mu \mathrm{M}$ Tat-ATOX1 protein. The transduction efficiency of Tat-ATOX1 protein was assessed by western blot analysis. As shown in Fig. 2A and B, we found that Tat-ATOX1 protein transduced into the RINm5F cells in a concentration- and time-dependent manner, whereas control ATOX1 protein did not transduce into the cells.

We further confirmed Tat-ATOX1 protein transduction by direct DAPI- and Alexa Fluor 488-staining using fluorescence confocal microscopy (Fig. 2C). In the cells treated with Tat-ATOX1 protein, green fluorescence was clearly visible in the nucleus and cytoplasm. By contrast, the cells treated with control ATOX1 protein did not exhibit green fluorescence. 


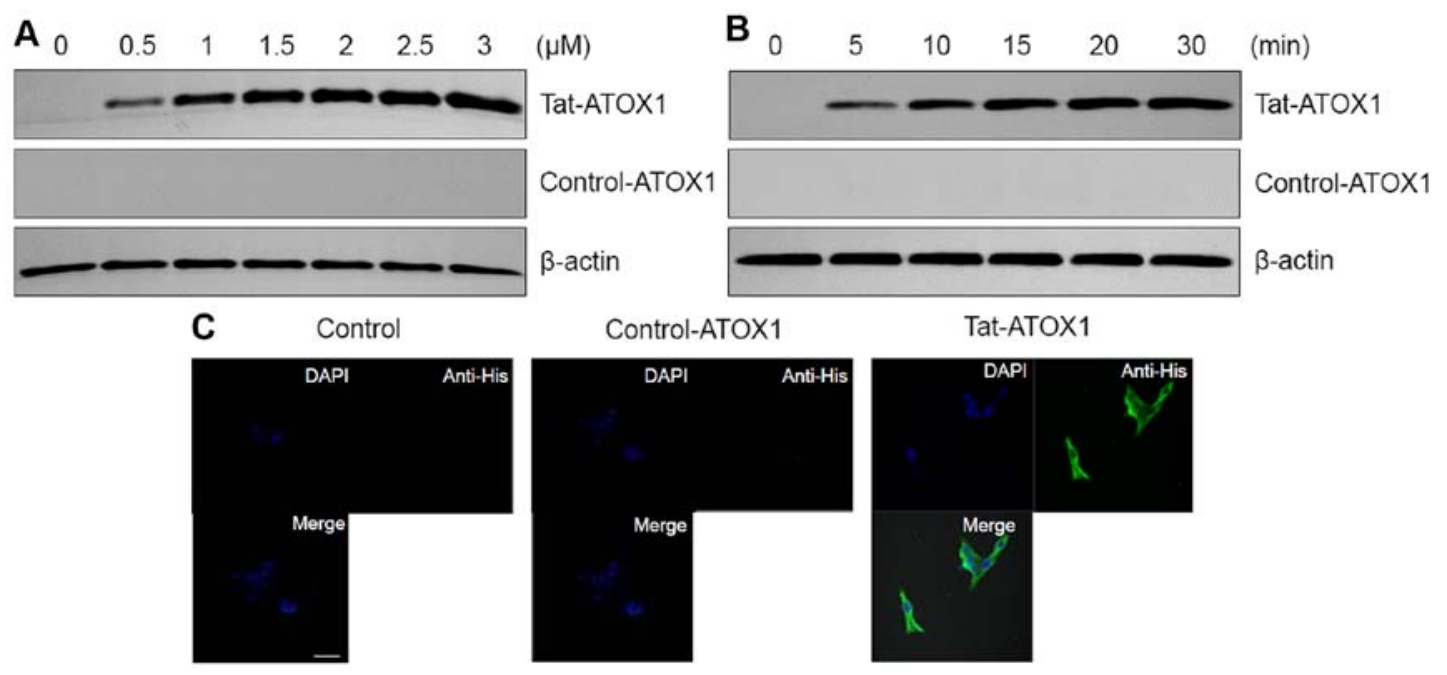

Figure 2. Transduction of Tat-antioxidant 1 (ATOX1) protein into RINm5F cells. (A) Tat-ATOX1 protein (0.5-3 $\mu \mathrm{M})$ and control ATOX1 protein were added to the culture media for $30 \mathrm{~min}$; (B) Tat-ATOX1 protein $(3 \mu \mathrm{M})$ and control ATOX1 protein were added to the culture media for 5-30 min, and analyzed by western blot analysis.(C) Intracellular distribution of the transduced Tat-ATOX1 protein was observed by fluorescence microscopy. Scale bar, $20 \mu \mathrm{m}$.
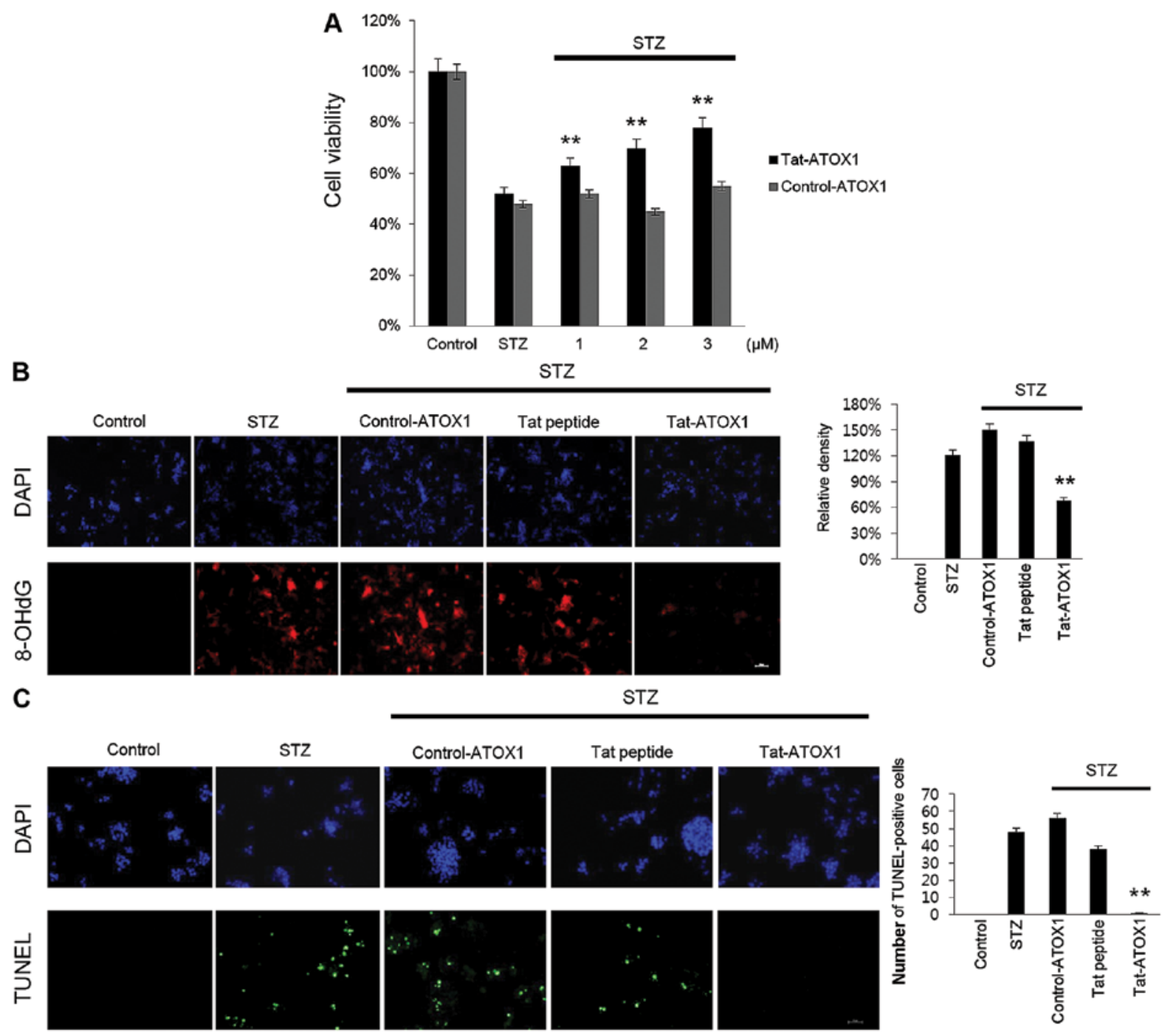

Figure 3. Inhibitory effects of Tat-antioxidant 1 (ATOX1) protein against streptozotocin (STZ)-induced cellular damage in RINm5F cells. RINm5F cells were exposed to STZ $(3 \mathrm{mM})$ for $12 \mathrm{~h}$ following treatment with Tat-ATOX1 and control ATOX1 protein $(1-3 \mu \mathrm{M})$ for 30 min. (A) Cell viability was analyzed by colorimetric assay using MTT; ${ }^{* *} \mathrm{P}<0.01$ compared with STZ-exposed RINm5F cells. (B and C) Cells were treated with Tat-ATOX1 protein ( $\left.3 \mu \mathrm{M}\right)$ for 30 min, and exposed to STZ ( $3 \mathrm{mM})$ for $24 \mathrm{~h}$. The protective effects of Tat-ATOX1 protein on 8-hydroxy-2'-deoxyguanosine (8-OHdG) and DNA fragmentation in STZ-exposed RINm5F cells were then measured by staining, and the fluorescence intensity was measured by an ELISA plate reader. Scale bar, $50 \mu \mathrm{m}$. ${ }^{* *} \mathrm{P}<0.01$ compared with STZ-treated cells. 
A

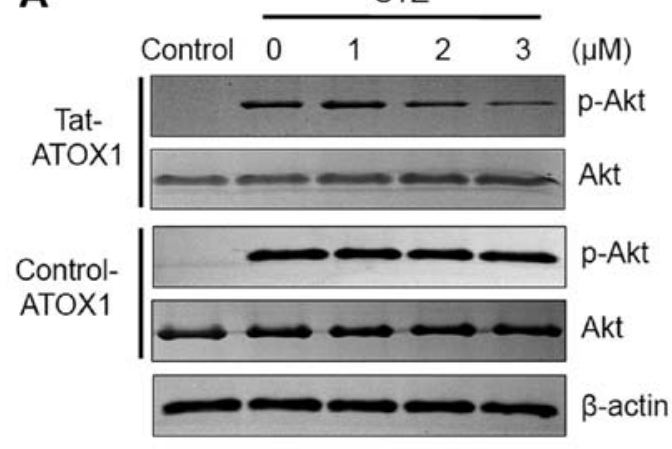

C

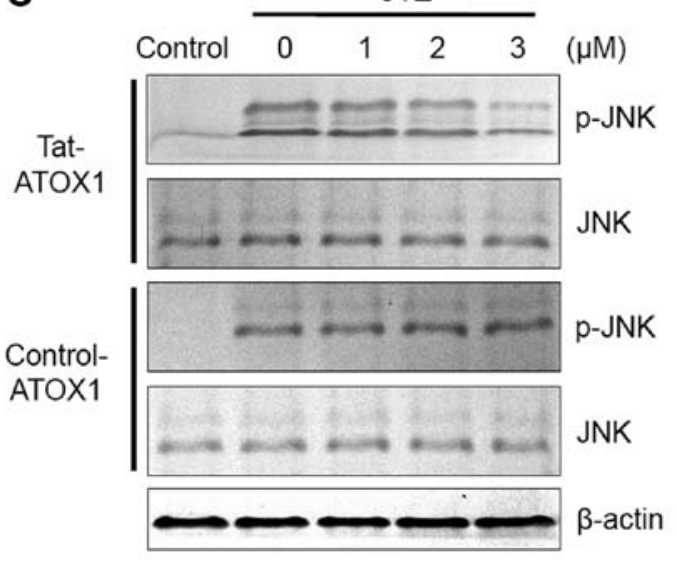

B

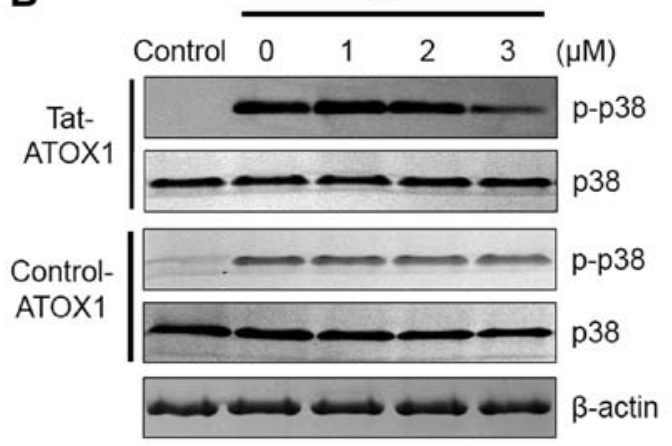

D

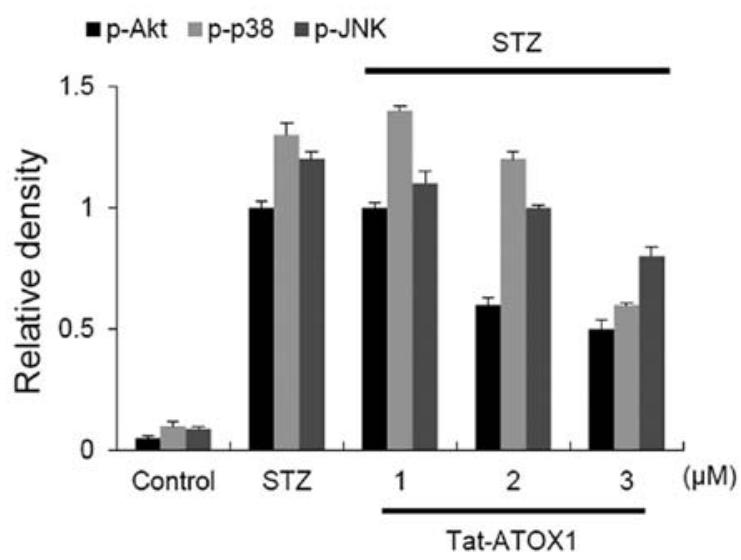

Figure 4. Inhibitory effects of Tat-antioxidant 1 (ATOX1) protein on streptozotocin (STZ)-induced mitogen activated protein kinase (MAPK) and Akt activation in RINm5F cells. Following treatment with Tat-ATOX1 and control ATOX1 protein (1-3 $\mu \mathrm{M})$ for 30 min, RINm5F cells were incubated with $3 \mathrm{mM}$ STZ for $8 \mathrm{~min}$ (Akt), $35 \mathrm{~min}$ (p38) and $45 \mathrm{~min}$ [c-Jun N-terminal kinase (JNK)], respectively. Phosphorylation of (A) Akt, (B) p38 and (C) JNK levels were determined by western blot analysis, and (D) the band intensity was measured by densitometry.

These results further confirm that Tat-ATOX1 protein transduced into the RINm5F cells.

Effect of transduced Tat-ATOX1 protein on STZ-induced cell damage. To examine the protective effect of Tat-ATOX1 protein on RINm5F cells, the cells were exposed to STZ (3 mM) for $12 \mathrm{~h}$, after which cell viability was assessed using an MTT assay. Cell viability was significantly decreased in the cells exposed to STZ (52\%) compared with the control cells, whereas in those cells treated with Tat-ATOX1 protein cell viability was markedly increased in a dose-dependent manner, up to $76 \%$. However, control ATOX1 protein exerted little or no protective effects under the same conditions (Fig. 3A).

As STZ induces DNA damage and cell death, we examined whether Tat-ATOX1 protein inhibits DNA fragmentation and the production of $8-\mathrm{OHdG}$, which is one of the major byproducts of DNA oxidation. Thus, we measured $8-\mathrm{OHdG}$ in the STZ-exposed cells. Transduced Tat-ATOX1 protein markedly reduced DNA oxidation in the STZ-exposed cells (Fig. 3B). DNA fragmentation was measured by TUNEL staining. As shown in Fig. 3C, the number of TUNEL-positive stained cells significantly increased in the STZ-exposed cells compared with that in the control cells. By contrast, the number of TUNEL-positive stained cells significantly decreased in the Tat-ATOX1 protein-treated cells. These results indicate that
Tat-ATOX1 protein protected against cell death by inhibiting DNA damage.

Effects of Tat-ATOX1 protein on STZ-induced activation of Akt and mitogen activated protein kinase (MAPK) in RINm5F cells. A previous study has demonstrated that STZ-induced diabetes in animals leads to apoptotic cell death through the activation of c-Jun N-terminal kinase (JNK), p38 and Akt (36). To examine the effects of Tat-ATOX1 protein on JNK, p38 and Akt in STZ-exposed RINm5F cells, the cells in this study were exposed to STZ $(3 \mathrm{mM})$ and evaluated by western blot analysis (Fig. 4). In the STZ-exposed cells, the expression of phosphorylated (p-)JNK, p-p38 and p-Akt was markedly increased. However, Tat-ATOX1 protein significantly reduced the levels of p-JNK, p-p38 and p-Akt in the STZ-exposed cells. By contrast, control ATOX1 protein did not seem to have any effect on these protein expression levels. These results indicate that Tat-ATOX1 protein protects cells by regulating the Akt and MARK (JNK and p38) signaling pathways.

Effect of Tat-ATOX1 protein on mice with STZ-induced diabetes. To determine the effects of Tat-ATOX1 protein on mice with STZ-induced diabetes, we examined the changes in blood glucose levels, body weight, and glycosylated HbA1C 

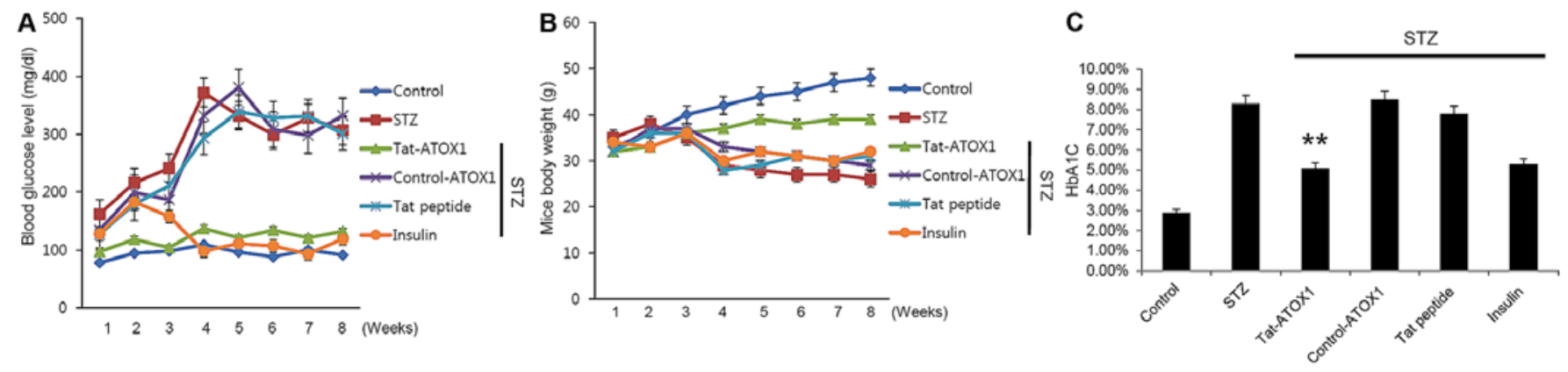

Figure 5. Tat-antioxidant 1 (ATOX1) protein attenuates streptozotocin (STZ)-induced diabetes in mice. Diabetes was induced by a single intraperitoneal injection of $70 \mathrm{mg} / \mathrm{kg}$ STZ. Tat-ATOX1 protein $(2 \mathrm{mg} / \mathrm{kg}$ ) was injected 6 times into the mice with STZ-induced diabetes, at weekly intervals. (A) Changes to blood glucose levels, (B) body weight and (C) hemoglobin Alc (HbA1c) levels were determined. ${ }^{* *} \mathrm{P}<0.01$ vs. the relevant group with STZ-induced diabetes.

A

Histidine
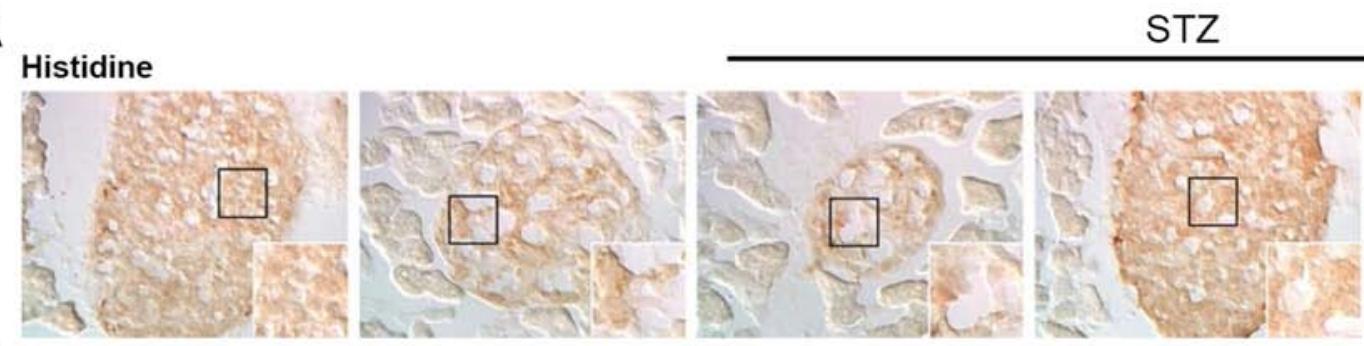

B
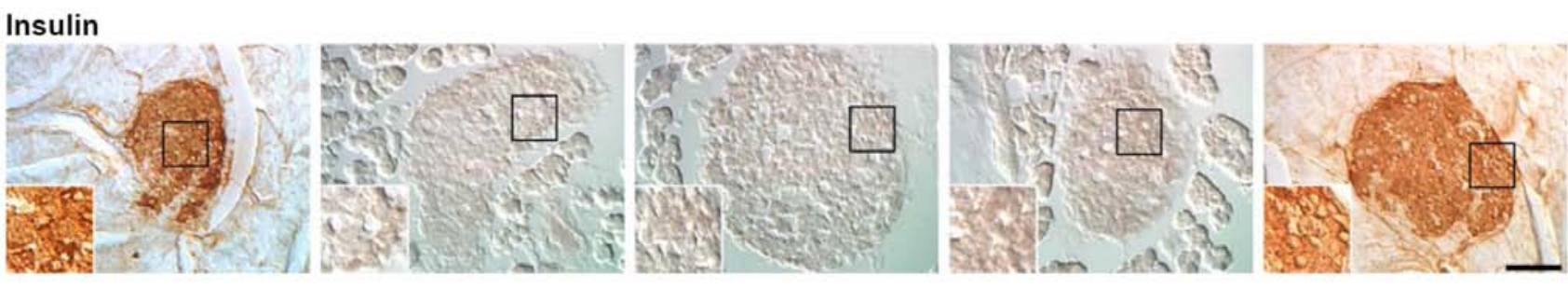

C

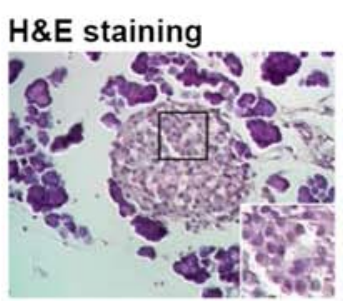

Control

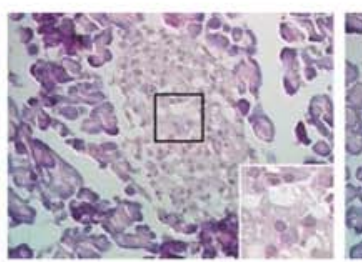

STZ

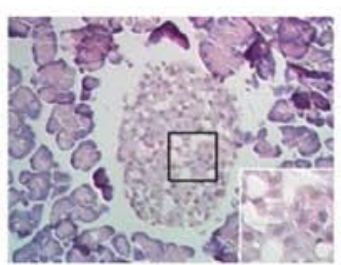

Control-ATOX1

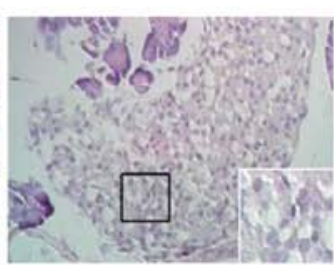

Tat peptide

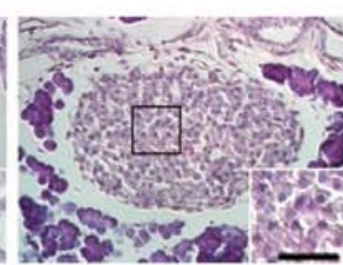

Tat-ATOX1

Figure 6. Protective effects of Tat-antioxidant 1 (ATOX1) protein in mice with streptozotocin (STZ)-induced diabetes. Diabetes was induced by a single intraperitoneal injection of $70 \mathrm{mg} / \mathrm{kg}$ STZ. Tat-ATOX1 protein $(2 \mathrm{mg} / \mathrm{kg}$ ) was injected 6 times into mice with STZ-induced diabetes, at weekly intervals. Pancreatic tissue sections were incubated with (A) an anti-rabbit polyhistidine antibody, (B) anti-mouse insulin antibody and stained with a peroxidase/DAB system or (C) hematoxylin and eosin (H\&E). Black boxes denote areas seen at higher magnification and are presented in either the lower right corner or the lower left corner of the panels. Scale bar, $100 \mu \mathrm{m}$ except for $50 \mu \mathrm{m}$ at a high magnification.

levels. In the STZ-exposed mice, blood glucose levels and HbA1C levels were markedly increased compared with those in the untreated normal control group. By contrast, body weight was significantly reduced in the mice with STZ-induced diabetes. However, Tat-ATOX1 protein normalized or markedly ameliorated these effects mentioned above. These changes were also normalized or ameliorated in the mice treated with insulin, a reference drug which was used in order to examine the effects of insulin in comparison with Tat-ATOX1 protein. There were no significant differences between the other groups (control ATOX1 protein- and Tat peptide-treated groups) and the group with STZ-induced diabetes (Fig. 5).
Furthermore, we also examined the effects of Tat-ATOX1 protein on the pancreatic tissue of mice with STZ-induced diabetes. As shown in Fig. 6, Tat-ATOX1 protein transduced into pancreatic tissues, where it provided significant protection against pancreatic $\beta$-cell destruction in the mice with STZ-induced diabetes. Furthermore, we demonstrated that Tat-ATOX1 protein markedly increased insulin levels compared with those in the mice with STZ-induced diabetes. However, control ATOX1 protein and Tat peptide did not exert the same protective effects. These results indicate that transduced Tat-ATOX1 protein prevented pancreatic $\beta$-cell destruction caused by STZ and attenuated STZ-induced diabetes in mice. 


\section{Discussion}

ATOX1 protein is a copper chaperone and plays an important role in copper homeostasis. Copper homeostasis is important for cellular biochemical processes, as free copper ions cause cellular toxicity through the generation of reactive oxygen species (ROS), resulting in cellular damage. ATOX1 is also known to play a roles in cells, as a copper transporter and antioxidant $(8,9,11)$. Other studies have demonstrated that the impairment of copper regulation is associated with various human diseases, including neuronal diseases, cardiomyopathy and diabetes $(8,14-19)$.

PTDs, including Tat, are well known for their ability to deliver proteins to cells and tissues (20-22). Previous studies have used this ability to demonstrate the protective effects of a variety of PTD-fusion proteins and thus, their potential for use as therapeutic agents in the management of numerous diseases (23-30). Therefore, in the present study, we generated a cell-permeable Tat-ATOX1 protein and examined the protective effects of Tat-ATOX1 protein against STZ-induced RINm5F cell death and in a mouse model of STZ-induced diabetes. As ATOX1 protein possesses a limited ability to transduce into cells, the application of this protein was also limited. We generated Tat-ATOX1 protein to solve this transduction problem. Purified Tat-ATOX1 protein was confirmed by SDS-PAGE and western blot analysis using an anti-His antibody. Moreover, we found that Tat-ATOX1 protein was efficiently transduced into the RINm5F cells in a time- and concentration-dependent manner. Also, fluorescence signals of transduced Tat-ATOX1 protein were distributed in the nucleus and cytoplasm of the cells. These results indicate that Tat-ATOX1 protein efficiently transduced into RINm5F cells. However, the transduction mechanism of Tat-ATOX1 protein requires further investigation, as it is not yet fully understood.

STZ is usually used to induce DM by causing pancreatic $\beta$-cell death through cytotoxic effects and DNA damage (37). We determined the effects of transduced Tat-ATOX1 protein on the cell viability of STZ-exposed RINm5F cells. We found that transduced Tat-ATOX1 protein significantly increased cell survival in a dose-dependent manner. Furthermore, we demonstrated that transduced Tat-ATOX1 protein prevented the DNA damage induced by STZ. Thus, we suggest that transduced Tat-ATOX1 protein protects against STZ-induced cell death by inhibiting DNA damage.

Both the phosphoinositide 3-kinase (PI3K)/Akt and MAPK signaling pathways are activated in response to various stimuli and are known to play important roles in cell survival and thus, they also play an important role in preventing cell death (36,38-41). In this study, we evaluated p-Akt and MAPK (p-JNK and p-p38) levels using western blot analysis. Tat-ATOX1 protein reduced p-Akt and MAPK (p-JNK and p-p38) expression levels in the STZ-exposed RINm5F cells, suggesting that transduced Tat-ATOX1 protein protects against cell death through the regulation of the Akt and MAPK (JNK and p38) signaling pathways.

STZ is the most frequently used agent to induce experimental diabetes in animal models, and STZ-induced diabetes is accompanied by destruction of pancreatic $\beta$-cells, loss of insulin secretion and alterations in blood glucose levels $(42,43)$. To induce diabetes in an animal model, in this study the mice were intraperitoneally injected with a single dose of STZ $(70 \mathrm{mg} / \mathrm{kg}$ ). After 8 weeks of STZ treatment, we observed the protective effects of Tat-ATOX1 protein in the mice with STZ-induced diabetes. We injected STZ-exposed mice six times with Tat-ATOX1 protein at weekly intervals. In the Tat-ATOX1 protein-treated group, blood glucose and glycated $\mathrm{HbA1C}$ levels were significantly decreased compared with the levels in the mice with STZ-induced diabetes which did not receive treatment. Tat-ATOX1 protein also markedly attenuated the loss of body weight induced by STZ. Additionally, we demonstrated that Tat-ATOX1 protein effectively transduced into pancreatic $\beta$-cells. Moreover, transduced Tat-ATOX1 protein protected against the destruction of pancreatic tissues and enhanced the levels of insulin secretion. Several studies have shown that various antioxidants prevent STZ-induced pancreatic damage (44-46). In this study, we demonstrated that Tat-ATOX1 protein exerted protective effects against cell damage induced by STZ in RINm5F cells as well as in a mouse model of STZ-induced diabetes, suggesting that Tat-ATOX1 protein has potential applications as a treatment for oxidative stress-induced diseases, including DM.

\section{Acknowledgements}

The present study was supported by a Priority Research Centers Program grant (no. NRF-2009-0093812) and in part by a grant (no. 2012R1A2A1A03006155) from the National Research Foundation of Korea funded by the Ministry of Science, ICT and Future Planning in the Republic of Korea, and it was also supported by a Basic Research Program (no. 2013R1A1A4A01009050) through the National Research Foundation of Korea funded by the Ministry of Education (no. 2014R1A1A4A01008026).

\section{References}

1. Global report on diabetes. World Health Organization, Geneva, 2016.

2. Stattin P, Björ O, Ferrari P, Lukanova A, Lenner P, Lindahl B, Hallmans $G$ and Kaaks R: Prospective study of hyperglycemia and cancer risk. Diabetes Care 30: 561-567, 2007.

3. Connolly GC, Safadjou S, Chen R, Nduaguba A, Dunne R, Khorana AA and Hezel AF: Diabetes mellitus is associated with the presence of metastatic spread at disease presentation in hepatocellular carcinoma. Cancer Invest 30: 698-702, 2012.

4. Li YG, Ji DF, Zhong S, Lin TB and Lv ZQ: Hypoglycemic effect of deoxynojirimycin-polysaccharide on high fat diet and streptozotocin-induced diabetic mice via regulation of hepatic glucose metabolism. Chem Biol Interact 225: 70-79, 2015.

5. Jin L, Xue HY, Jin LJ, Li SY and Xu YP: Antioxidant and pancreas-protective effect of aucubin on rats with streptozotocin-induced diabetes. Eur J Pharmacol 582: 162-167, 2008.

6. Kim MJ, Kim DW, Lee BR, Shin MJ, Kim YN, Eom SA, Park BJ, Cho YS, Han KH, Park J, et al: Transduced Tat-glyoxalase protein attenuates streptozotocin-induced diabetes in a mouse model. Biochem Biophys Res Commun 430: 294-300, 2013.

7. Koroglu P, Senturk GE, Yucel D, Ozakpinar OB, Uras F and Arbak S: The effect of exogenous oxytocin on streptozotocin (STZ)-induced diabetic adult rat testes. Peptides 63: 47-54, 2015.

8. Montes S, Rivera-Mancia S, Diaz-Ruiz A, Tristan-Lopez L and Rios C: Copper and copper proteins in Parkinson's disease. Oxid Med Cell Longev 2014: 147251, 2014.

9. Klomp LW, Lin SJ, Yuan DS, Klausner RD, Culotta VC and Gitlin JD: Identification and functional expression of HAH1, a novel human gene involved in copper homeostasis. J Biol Chem 272: 9221-9226, 1997. 
10. Liu YY, Nagpure BV, Wong PT and Bian JS: Hydrogen sulfide protects SH-SY5Y neuronal cells against d-galactose induced cell injury by suppression of advanced glycation end products formation and oxidative stress. Neurochem Int 62: 603-609, 2013.

11. Cai H and Peng F: Knockdown of copper chaperone antioxidant-1 by RNA interference inhibits copper-stimulated proliferation of non-small cell lung carcinoma cells. Oncol Rep 30: 269-275, 2013.

12. Uauy R, Olivares M and Gonzalez M: Essentiality of copper in humans. Am J Clin Nutr 67 (Suppl): 952S-959S, 1998.

13. Díez M, Arroyo M, Cerdàn FJ, Muñoz M, Martin MA and Balibrea JL: Serum and tissue trace metal levels in lung cancer. Oncology 46: 230-234, 1989.

14. Ozumi K, Sudhahar V, Kim HW, Chen GF, Kohno T, Finney L, Vogt S, McKinney RD, Ushio-Fukai M and Fukai T: Role of copper transport protein antioxidant 1 in angiotensin II-induced hypertension: a key regulator of extracellular superoxide dismutase. Hypertension 60: 476-486, 2012.

15. Lin SJ and Culotta VC: The ATX1 gene of Saccharomyces cerevisiae encodes a small metal homeostasis factor that protects cells against reactive oxygen toxicity. Proc Natl Acad Sci USA 92: 3784-3788, 1995.

16. Kelner GS, Lee M, Clark ME, Maciejewski D, McGrath D, Rabizadeh S, Lyons T, Bredesen D, Jenner P and Maki RA: The copper transport protein Atox1 promotes neuronal survival. J Biol Chem 275: 580-584, 2000.

17. Itoh S, Ozumi K, Kim HW, Nakagawa O, McKinney RD, Folz RJ, Zelko IN, Ushio-Fukai M and Fukai T: Novel mechanism for regulation of extracellular SOD transcription and activity by copper: role of antioxidant-1. Free Radic Biol Med 46: 95-104, 2009.

18. Dolgova NV, Nokhrin S, Yu CH, George GN and Dmitriev OY: Copper chaperone Atox1 interacts with the metal-binding domain of Wilson's disease protein in cisplatin detoxification. Biochem J 454: 147-156, 2013.

19. Zhang S, Liu H, Amarsingh GV, Cheung CC, Hogl S, Narayanan U, Zhang L, McHarg S, Xu J, Gong D, et al: Diabetic cardiomyopathy is associated with defective myocellular copper regulation and both defects are rectified by divalent copper chelation. Cardiovasc Diabetol 13: 100-118, 2014.

20. Wadia JS and Dowdy SF: Protein transduction technology. Curr Opin Biotechnol 13: 52-56, 2002.

21. Dietz GP: Cell-penetrating peptide technology to deliver chaperones and associated factors in diseases and basic research. Curr Pharm Biotechnol 11: 167-174, 2010.

22. van den Berg A and Dowdy SF: Protein transduction domain delivery of therapeutic macromolecules. Curr Opin Biotechnol 22: 888-893, 2011.

23. Kubo E, Fatma N, Akagi Y, Beier DR, Singh SP and Singh DP: TAT-mediated PRDX6 protein transduction protects against eye lens epithelial cell death and delays lens opacity. Am J Physiol Cell Physiol 294: C842-C855, 2008.

24. Kwon HY, Eum WS, Jang HW, Kang JH, Ryu J, Ryong Lee B, Jin LH, Park J and Choi SY: Transduction of $\mathrm{Cu}, \mathrm{Zn}$-superoxide dismutase mediated by an HIV-1 Tat protein basic domain into mammalian cells. FEBS Lett 485: 163-167, 2000.

25. Embury J, Klein D, Pileggi A, Ribeiro M, Jayaraman S, Molano RD, Fraker C, Kenyon N, Ricordi C, Inverardi L and Pastori RL: Proteins linked to a protein transduction domain efficiently transduce pancreatic islets. Diabetes 50: 1706-1713, 2001.

26. Kim DW, Lee SH, Jeong MS, Sohn EJ, Kim MJ, Jeong HJ, An JJ, Jang SH, Won MH and Hwang IK: Transduced Tat-SAG fusion protein protects against oxidative stress and brain ischemic insult. Free Radic Biol Med 48: 969-977, 2010.

27. Shin MJ, Kim DW, Lee YP, Ahn EH, Jo HS, Kim DS, Kwon OS Kang TC, Cho YJ, Park J, et al: Tat-glyoxalase protein inhibits against ischemic neuronal cell damage and ameliorates ischemic injury. Free Radic Biol Med 67: 195-210, 2014

28. Kim HR, Kim DW, Jo HS, Cho SB, Park JH, Lee CH, Choi YJ, Yeo EJ, Park SY, Kim ST, et al: Tat-biliverdin reductase A inhibits inflammatory response by regulation of MAPK and NF- $\kappa$ B pathways in Raw 264.7 cells and edema mouse model. Mol Immunol 63: 355-366, 2015.
29. Kim DW, Lee SH, Ku SK, Cho SH, Cho SW, Yoon GH, Hwang HS, Park J, Eum WS, Kwon OS and Choi SY: Transduced PEP-1-FK506BP ameliorates corneal injury in Botulinum toxin A-induced dry eye mouse model. BMB Rep 46: 124-129, 2013.

30. Youn JK, Kim DW, Kim ST, Park SY, Yeo EJ, Choi YJ, Lee HR, Kim DS, Cho SW, Han KH, et al: PEP-1-HO-1 prevents MPTP-induced degeneration of dopaminergic neurons in a Parkinson's disease mouse model. BMB Rep 47: 569-574, 2014.

31. Bradford MM: A rapid and sensitive method for the quantitation of microgram quantities of protein utilizing the principle of protein-dye binding. Anal Biochem 72: 248-254, 1976.

32. Kwon DJ, Bae YS, Ju SM, Youn GS, Choi SY and Park J: Salicortin suppresses lipopolysaccharide-stimulated inflammatory responses via blockade of NF- $\kappa \mathrm{B}$ and JNK activation in RAW 264.7 macrophages. BMB Rep 47: 318-323, 2014.

33. Ninomiya Y, Cui X, Yasuda T, Wang B, Yu D, Sekine-Suzuki E and Nenoi M: Arsenite induces premature senescence via p53/p21 pathway as a result of DNA damage in human malignant glioblastoma cells. BMB Rep 47: 575-580, 2014.

34. Im CN and Seo JS: Overexpression of tumor necrosis factor receptor-associated protein 1 (TRAP1), leads to mitochondrial aberrations in mouse fibroblast NIH/3T3 cells. BMB Rep 47: 280-285, 2014.

35. Kim YM, Lee SM and Chung HS: Novel AGLP-1 albumin fusion protein as a long-lasting agent for type 2 diabetes. BMB Rep 46: 606-610, 2013.

36. Melloul D: Role of NF-kappaB in $\beta$-cell death. Biochem Soc Trans 36: 334-339, 2008.

37. Szkudelski T: The mechanism of alloxan and streptozotocin action in B cells of the rat pancreas. Physiol Res 50: 537-546, 2001.

38. Mo L, Yang C, Gu M, Zheng D, Lin L, Wang X, Lan A, Hu F and Feng J: PI3K/Akt signaling pathway-induced heme oxygenase-1 upregulation mediates the adaptive cytoprotection of hydrogen peroxide preconditioning against oxidative injury in PC12 cells. Int J Mol Med 30: 314-320, 2012.

39. Angeloni C, Motori E, Fabbri D, Malaguti M, Leoncini E, Lorenzini A and Hrelia $\mathrm{S}: \mathrm{H}_{2} \mathrm{O}_{2}$ preconditioning modulates phase II enzymes through p38 MAPK and PI3K/Akt activation. Am J Physiol Heart Circ Physiol 300: H2196-H2205, 2011.

40. Nishimoto T, Matsumoto A, Kihara T, Akaike A and Sugimoto H: Protective effect of $\mathrm{H}_{2} \mathrm{O}_{2}$ against subsequent $\mathrm{H}_{2} \mathrm{O}_{2}$-induced cytotoxicity involves activation of the PI3K-Akt signaling pathway. Cell Mol Biol (Noisy-le-grand) 56 (Suppl): OL1447-OL1452, 2010.

41. Jiang $X$, Tang $X$, Zhang $P$, Liu $G$ and Guo H: Cyanidin3-O- $\beta$-glucoside protects primary mouse hepatocytes against high glucose-induced apoptosis by modulating mitochondrial dysfunction and the PI3K/Akt pathway. Biochem Pharmacol 90: 135-144, 2014.

42. Rakieten N, Rakieten ML and Nadkarni MV: Studies on the diabetogenic action of streptozotocin (NSC-37917). Cancer Chemother Rep 29: 91-98, 1963.

43. Junod A, Lambert AE, Stauffacher W and Renold AE: Diabetogenic action of streptozotocin: relationship of dose to metabolic response. J Clin Invest 48: 2129-2139, 1969.

44. Bonnefont-Rousselot D: The role of antioxidant micronutrients in the prevention of diabetic complications. Treat Endocrinol 3: 41-52, 2004.

45. Samarghandian S, Borji A, Delkhosh MB and Samini F: Safranal treatment improves hyperglycemia, hyperlipidemia and oxidative stress in streptozotocin-induced diabetic rats. J Pharm Pharm Sci 16: 352-362, 2013

46. Pi J, Zhang Q, Fu J, Woods CG, Hou Y, Corkey BE, Collins S and Andersen ME: ROS signaling, oxidative stress and Nrf2 in pancreatic beta-cell function. Toxicol Appl Pharmacol 244: 77-83, 2010. 